\title{
Irrigated sugarcane crops improve the quality of soil organic carbon over time
}

\section{O cultivo da cana-de-açúcar irrigada melhora a qualidade do carbono orgânico do solo ao longo do tempo}

\author{
Verônica Aparecida Santos Ferreira Soares ${ }^{1}$; Leidivan Almeida Frazão2; Rodinei \\ Facco Pegoraro2; Regynaldo Arruda Sampaio²; Luiz Arnaldo Fernandes ${ }^{2 *}$
}

\section{Highlights}

Organic residues from sugarcane harvesting improve the soil physical attributes.

The sugarcane crop increases the more stable fractions of soil organic matter.

Mechanized sugarcane harvesting increases the soil carbon stock over time.

\begin{abstract}
The substitution of native vegetation in agricultural systems can cause several changes in the chemical and physical soil attributes, and in the dynamics of soil organic carbon. This study aimed to evaluate changes in soil physical attributes and carbon stock in soil organic matter fractions in irrigated sugarcane crops, as a function of land use and straw management practices over time, in the North of Minas Gerais State, Brazil. Four sugarcane fields with different ages and management systems were studied: Cane 6, Cane 7, Cane 8, and Cane 10. The data obtained were compared with a native vegetation area located near the sugarcane fields, and used as reference for unmanaged soil. In each system, soil samples were collected in the 0-10, 10-20, and 20-30 cm depth layers, to determine the physical attributes, the total organic carbon, and the physical fractions of the soil organic matter. We found that the sugarcane management with the maintenance of a part of the straw on the soil surface contributes to the preservation of the soil structure and the most stable fractions of organic carbon over time. However, in the regions with high annual mean temperature and in the irrigated systems, the soil tillage for the renewal of the sugarcane fields significantly decreases the total soil organic carbon.
\end{abstract}

Key words: Soil quality. Soil management. Soil organic matter fractions.

1 Doctoral Student at the Graduate Program in Crop Science, Universidade Federal de Minas Gerais, UFMG, Montes Claros, MG, Brazil. E-mail: veronicaasf@yahoo.com.br

2 Profs. Drs., UFMG, Montes Claros, MG, Brazil. E-mail: leidivan.frazao@gmail.com; rodinei_pegoraro@yahoo.com.br; regynaldo@terra.com.br; luizmcmg@gmail.com

* Author for correspondence

Received: June 17, 2021 - Approved: Nov. 11, 2021 


\section{Resumo}

A substituição de áreas de vegetação nativa em áreas agrícolas pode causar diversas alterações nos atributos químicos e físicos e na dinâmica do carbono orgânico do solo. Este estudo teve como objetivo avaliar mudanças nos atributos físicos e no estoque de carbono nas frações de matéria orgânica do solo em canaviais irrigados, em função do uso da terra e das práticas de manejo da palhada, no Norte do Estado de Minas Gerais. Foram estudados quatro canaviais com diferentes idades e sistemas de manejo: Cana 6, Cana 7. Cana 8 e Cana 10. Os dados obtidos foram comparados com os do solo de área de vegetação nativa, próxima aos canaviais, como referência de solo não manejado. Em cada uma das áreas foram coletadas amostras de solo nas camadas de 0-10, 10-20, and 20-30 cm de profundidade, para a determinação dos atributos físicos, carbono orgânico total e fracionamento físico da matéria orgânica do solo. De acordo com os resultados obtidos, o manejo dos canaviais com a manutenção de parte da palha na superfície do solo contribui para a preservação da estrutura do solo e das frações mais estáveis do carbono orgânico ao longo do tempo. Porém, em regiões de alta temperatura média anual e em sistemas irrigados, o preparo do solo para a renovação dos canaviais diminui significativamente o carbono orgânico total do solo.

Palavras-chave: Qualidade do solo. Manejo do solo. Fracionamento da matéria orgânica.

\section{Introduction}

Brazil is one of the largest producers of sugar and sugarcane ethanol, and the area cultivated with this crop is constantly expanding (Instituto Brasileiro de Geografia e Estatítica [IBGE], 2017). In recent years, areas not recommended for intensive agriculture due to the occurrence of prolonged dry seasons throughout the year, have been used for the irrigated crops of sugarcane for ethanol production.

The Northern region of Minas Gerais State has been cultivated with irrigated sugarcane for ethanol production and is characterized by high temperature throughout the year and long periods of water deficit (Alvares, Stape, Sentelhas, Goncalves, \& Sparovek., 2013), usually from April to October, restricting land use for agriculture without irrigation. The substitution of native vegetation with sugarcane monocultures (cultivation of a single crop) can cause serious problems of degradation of soil properties (Luciano, Albuquerque, Costa, Batistella, \& Warmling, 2012). In addition, management practices, such as irrigation and mechanization of sugarcane fields, can alter the dynamics of soil organic carbon over time.

The use of irrigation systems in this region has been shown to be a viable solution for relatively large sugarcane monocultures, mainly in sandy soils with low water holding capacity. In this context, irrigation represents a revolution in the technology of sugarcane growth, since it contributes to increasing the productivity and longevity of the sugarcane fields (Simões, Calgaro, Coelho, de Souza, \& Lima, 2015). However, the local edaphoclimatic conditions, combined with irrigation management and the application of soil acidity correctives and soluble mineral fertilizers, can lead to relatively fast decomposition of organic matter and, consequently, altering the soil properties over the short term. According to Bordonal et al. (2018), the soil organic carbon 
stocks in the sugarcane fields are variable due to the edaphoclimatic conditions, therefore, it is necessary to establish critical levels of straw removal according to the local environmental conditions and soil texture.

In this study, we evaluated the changes in soil physical attributes and carbon stock in soil organic matter fractions in irrigated sugarcane crops as a function of land use and straw management practices over time. We hypothesized that sugarcane straw residues, that result from mechanized harvesting, improve soil physical attributes and increase soil carbon stock over time, even in irrigated crops installed in regions with high temperatures throughout the year.

\section{Material and Methods}

In this study, soil samples were collected from an area with the same type of soil (Oxisol) and topography (0-3\% slope), from four sugarcane fields and a forest (native vegetation, unmanaged). The study area is located in the municipality of Jaíba $\left(15^{\circ} 11^{\prime} 29^{\prime \prime S}\right.$ and $\left.43^{\circ} 56^{\prime} 16^{\prime \prime} \mathrm{W}\right)$, which has an Aw-typeclimate, according to the Köppen classification, with dry winter, annual mean temperature above $20^{\circ} \mathrm{C}$ and annual precipitation between 700 to $1000 \mathrm{~mm}$, concentrated from October to April (Alvares et al., 2013). The native vegetation is characterized by a transition between Cerrado (Savanna) and Seasonal Deciduous Forest (Carvalho \& Scolforo, 2008).

The sugarcane fields were selected according to age and straw management: cane systems 10, 8, 7, and 6 . The forest was included in the study as a reference for soil in natural conditions without management (Figure 1). In the Cane 10 system, the first sugarcane field was established in 2005, immediately after the native vegetation was cleared. During the five years of sugarcane cultivation, all the plant straw (100\%) from mechanized harvesting was retained on the soil surface. After five years, the soil was tilled again and a new sugarcane field was established in 2010. In this second sugarcane field, $20 \%$ of the plant straw from mechanized harvesting was retained on the soil surface.

\begin{tabular}{|c|c|c|c|c|c|c|c|c|c|c|c|}
\hline System $\downarrow$ & $\begin{array}{c}\text { Year } \\
\rightarrow\end{array}$ & 2005 & 2006 & 2007 & 2008 & 2009 & 2010 & 2011 & 2012 & 2013 & 2014 \\
\hline Forest & \multicolumn{11}{|c|}{ Native vegetation (NV) } \\
\hline Cane 10 & NV & \multicolumn{5}{|c|}{ Sugarcane, 5 years, $100 \%$ straw } & \multicolumn{5}{|c|}{ Sugarcane, 5 years, $50 \%$ straw } \\
\hline Cane 8 & \multicolumn{3}{|c|}{ NV } & Peppe & years & \multicolumn{5}{|c|}{ Sugarcane, 5 years, $100 \%$ straw } & $\begin{array}{c}\text { Sugarcane, } \\
1 \text { year, } \\
50 \% \text { straw }\end{array}$ \\
\hline Cane 7 & \multirow{2}{*}{\multicolumn{5}{|c|}{ NV }} & \multicolumn{4}{|c|}{ ugarcane, 5 years, $100 \%$ straw } & $\begin{array}{c}\text { Common } \\
\text { bean, } 1 \\
\text { year }\end{array}$ & $\begin{array}{c}\text { Sugarcane, } \\
1 \text { year, } \\
50 \% \text { straw }\end{array}$ \\
\hline Cane 6 & & & & & & \multicolumn{6}{|c|}{ Sugarcane, 6 years, $20 \%$ straw } \\
\hline
\end{tabular}

Figure 1. Illustration of the land use history of the studied systems. 
In the Cane 8 system, after the removal of native vegetation in 2006, pepper was cultivated for two years. In 2008, the first sugarcane field was established and all the plant straw (100\%) from mechanized harvesting was retained on the soil surface. In 2013, after harvesting, the soil was tilled again and a new sugarcane field was established. In this second sugarcane field, $50 \%$ of the plant straw from mechanized harvesting was retained on the soil surface.

In the Cane 7 system, after the forest was cleared in 2007, the first sugarcane field was established and all the plant straw (100\%) from mechanized harvesting was retained on the soil surface. In 2012, after sugarcane harvesting, the soil was tilled again and was cultivated with common bean plants for a year. In 2013, the second sugarcane field was established and $50 \%$ of the plant straw from mechanized harvesting was retained on the soil surface. The Cane 6 system was implemented after the removal of native vegetation in 2008. In this system, after mechanized harvesting, $20 \%$ of the sugarcane straw was retained on the soil surface.

In all sugarcane systems, conventional soil tillage was used, with plowing, harrowing, and correction of soil acidity with limestone, according to the results of soil analysis, to increase base saturation to $60 \%$. With each new sugarcane field establishment, $120 \mathrm{~kg} \mathrm{ha}^{-1}$ of $\mathrm{P}_{2} \mathrm{O}_{5}$ was applied to the bottom of the furrow. The phosphorus sources were fertilizers formulated with NPK, with the proportions of $N, P$, and $K$ in the formulas varying over the years. The fertilizer supplements with nitrogen and potassium were made via fertigation, in order to apply, on average, depending on the development of the plants, $120 \mathrm{~kg} \mathrm{ha}^{-1}$ of $\mathrm{N}$ and $120 \mathrm{~kg} \mathrm{ha}^{-1}$ of $\mathrm{K}_{2} \mathrm{O}$, as urea and potassium chloride, respectively. After each harvest, were applied, on average, $120 \mathrm{~kg} \mathrm{ha}^{-1}$ of $\mathrm{N}, 25 \mathrm{~kg} \mathrm{ha}^{-1}$ of $\mathrm{P}_{2} \mathrm{O}_{5}$ and $120 \mathrm{~kg} \mathrm{ha}^{-1}$ of $\mathrm{K}_{2} \mathrm{O}$, via fertigation, using urea, monoammonium phosphate, and potassium chloride.

Soil samples were taken at 0-10, 10-20, and 20-30 cm depths, by opening mini trenches in January 2014, two months after harvest. For the analysis of soil density, undisturbed samples were collected from each layer using volumetric rings. In each study system, six trenches were opened in a row and six were opened in a planting row.

The texture of the soil samples was determined by the pipette method, according to Teixeira, Donagemma, Fontana and Teixeira (2013) and the total organic carbon was analyzed by dry combustion in an elemental analyzer (LECO CN-412).

The physical fractionation of soil organic matter was carried out according to Christensen (1992), in which particle sizes were separated by dispersion, wet sieving, and sedimentation. The samples were passed through a $2 \mathrm{~mm}$ mesh sieve, $20 \mathrm{~g}$ of the sample was placed in a glass flask, and then $70 \mathrm{~mL}$ of deionized water was added. Following this, the samples were taken to a cold chamber $\left(5^{\circ} \mathrm{C}\right)$, where they remained for two weeks. After the period, the samples were sonified with the aid of an ultrasound device for 15 minutes, with an amplitude of $70 \%$. The dispersed samples were passed through a $53 \mu \mathrm{m}$ sieve. The material that passed through the $53 \mu \mathrm{m}$ sieve corresponded to the silt and clay fraction of the soil organic matter (silt + clay fraction).

The material that was retained in the sieve (> $53 \mu \mathrm{m}$ ) was transferred to a crucible, mixed with deionized water and shaken manually (circular movements) to separate, 
by density, the light fraction from the sand fraction.

The materials from the different fractions of soil organic matter were separated into three subsamples and placed in small aluminum capsules. Following this, the subsamples were dried in a circulation and air renewal oven at a temperature of $40^{\circ} \mathrm{C}$. After drying, the subsamples were weighed, ground to 100 mesh-size and carbon was determined by dry combustion method in an elemental analyzer (LECO CN-412).

For each variable, the mean and the confidence interval were estimated by Student's t-test at $5 \%$ probability. Considering the multivariate structure contained in the data, statistical techniques were used to verify similarities between the systems to group them in terms of physical and chemical attributes. Cluster analysis was performed using a hierarchical method, using Euclidean distance as a measure of similarity between records and Ward's method as a clustering strategy.

\section{Results and Discussion}

The soils in sugarcane fields showed lower clay contents at $0-30 \mathrm{~cm}$ depth layer when compared to unmanaged soil (native vegetation) (Table 1). These results indicate that the conversion of the native vegetation to crops contributed to the eluviation of clay from the superficial layers to the deeper layers in the soil. The eluviation of clay is a natural process that can increase by cultivation, due to changes in the soil structure that provide a greater degree of clay dispersion in relation to its original conditions (Spera, Santos, Fontaneli, \& Tomm, 2008).

The soil density in the most superficial layers of native vegetation and Cane 8, were slightly lower than in the other systems (Table 1). The lower soil density in the native vegetation system is certainly related to the lack of mechanization. However, in the Cane 8 system, the maintenance of $50 \%$ of the straw (approximately $12 \mathrm{Mg} \mathrm{ha}^{-1}$ of leaves and tips of plants deposited annually on the soil surface) during the past five years may have contributed to the improvement of the soil structure, consequently leading to lower soil density values. 
Table 1

Texture (sand, silt, and clay), soil density, particle density, and total porosity from soil samples collected from different depths of sugarcane systems and native vegetation

\begin{tabular}{|c|c|c|c|c|c|}
\hline Depth (m) & Cane 6 & Cane 7 & Cane 8 & Cane 10 & Native vegetation \\
\hline & \multicolumn{5}{|c|}{ Sand $\left(\mathrm{g} \mathrm{kg}^{-1}\right)$} \\
\hline $0,0-0,1$ & $780 \mathrm{cB}$ & $820 b B$ & $780 \mathrm{cA}$ & $860 \mathrm{aA}$ & $720 c A$ \\
\hline $0,1-0,2$ & $800 \mathrm{bA}$ & $860 a A$ & $780 \mathrm{bA}$ & $860 a A$ & $700 \mathrm{cB}$ \\
\hline \multirow[t]{2}{*}{$0,2-0,3$} & $700 b c$ & $860 \mathrm{aA}$ & $720 b B$ & $840 a B$ & $660 c \mathrm{C}$ \\
\hline & \multicolumn{5}{|c|}{ Silt $\left(\mathrm{g} \mathrm{kg}^{-1}\right)$} \\
\hline $0,0-0,1$ & $100 \mathrm{bB}$ & $100 \mathrm{bA}$ & $100 b A$ & $80 c A$ & $120 a A$ \\
\hline $0,1-0,2$ & $80 b C$ & $80 b B$ & $80 b B$ & $80 b A$ & $100 \mathrm{aB}$ \\
\hline \multirow[t]{2}{*}{$0,2-0,3$} & $120 a A$ & $60 \mathrm{dC}$ & $80 c B$ & 80cA & $100 \mathrm{bB}$ \\
\hline & \multicolumn{5}{|c|}{ Clay $\left(\mathrm{g} \mathrm{kg}^{-1}\right)$} \\
\hline $0,0-0,1$ & $120 \mathrm{bB}$ & $80 \mathrm{dA}$ & $120 b C$ & $60 \mathrm{cB}$ & $160 \mathrm{aC}$ \\
\hline $0,1-0,2$ & $120 \mathrm{cB}$ & $60 \mathrm{~dB}$ & $140 b B$ & $60 \mathrm{~dB}$ & $200 a B$ \\
\hline \multirow[t]{2}{*}{$0,2-0,3$} & $180 \mathrm{cA}$ & $80 \mathrm{dA}$ & $200 \mathrm{bA}$ & 80dA & $240 a A$ \\
\hline & \multicolumn{5}{|c|}{ Soil density $\left(\mathrm{kg} \mathrm{dm}^{-3}\right)$} \\
\hline $0,0-0,1$ & $1,37 a A$ & $1,34 a A$ & $1,16 \mathrm{bA}$ & $1,37 a A$ & $1,10 \mathrm{cB}$ \\
\hline $0,1-0,2$ & $1,24 b B$ & $1,30 \mathrm{aB}$ & $1,08 c C$ & $1,27 b C$ & $1,05 c \mathrm{C}$ \\
\hline \multirow[t]{2}{*}{$0,2-0,3$} & $1,35 \mathrm{aA}$ & $1,26 b C$ & $1,14 \mathrm{~dB}$ & $1,35 a A$ & $1,19 \mathrm{cA}$ \\
\hline & \multicolumn{5}{|c|}{ Particles density $\left(\mathrm{kg} \mathrm{dm}^{-3}\right)$} \\
\hline $0,0-0,1$ & $2,63 \mathrm{bA}$ & $2,61 b A$ & $2,54 \mathrm{cA}$ & $2,69 a A$ & $2,57 \mathrm{cA}$ \\
\hline $0,1-0,2$ & $2,64 a A$ & $2,62 \mathrm{aA}$ & $2,55 \mathrm{cA}$ & $2,64 a B$ & $2,59 b A$ \\
\hline \multirow[t]{2}{*}{$0,2-0,3$} & $2,61 \mathrm{bA}$ & $2,63 a A$ & $2,55 \mathrm{cA}$ & $2,60 \mathrm{bB}$ & $2,60 \mathrm{bA}$ \\
\hline & \multicolumn{5}{|c|}{ Total porosity (\%) } \\
\hline $0,0-0,1$ & $48,34 \mathrm{bB}$ & $49,24 b A$ & $50,39 b B$ & $49,07 \mathrm{bA}$ & $57,20 a A$ \\
\hline $0,1-0,2$ & $53,21 \mathrm{bA}$ & $50,38 \mathrm{bA}$ & $57,65 a A$ & $52,08 \mathrm{bA}$ & $59,46 a A$ \\
\hline $0,2-0,3$ & $48,28 c B$ & $52,09 \mathrm{bA}$ & $55,29 a A$ & $47,88 \mathrm{cA}$ & $54,05 a B$ \\
\hline
\end{tabular}

. *Means followed by the same lowercase letter in the row and uppercase in the column do not differ by Student's $t$ test at $5 \%$ probability.

In the Cane 7 system, although the current sugarcane field was of the same age as that of the Cane 8 system and the same amount of straw was retained on the soil surface $(50 \%)$, the previous cultivation was with beans, while in the Cane 8 system the previous cultivation had also been with sugarcane, with retention of $100 \%$ of the straw on the soil surface. On the other hand, Cane 6 and Cane 10 systems showed the highest soil density values (Table
1), possibly due to the lower maintenance of straw (20\%) on the soil surface in the previous years (Figure 1).

Some authors consider that bulk density can be an efficient indicator of soil quality, since it is highly sensitive to soil management and is directly related to porosity, water infiltration, surface runoff, growth of the root system, and nutrient uptake 
by plants (Silva et al., 2013). In this study, it was found that, in general, the lower soil density was associated with higher soil total porosity (Table 1).

The soil total organic carbon (TOC) contents ranged from $4.7 \mathrm{~g} \mathrm{~kg}^{-1}$ (Cane 7, 20$30 \mathrm{~cm}$ ) to $14.5 \mathrm{~g} \mathrm{~kg}^{-1}$ (Cane 10, 0-10 cm) in the evaluated systems (Table 2). In the 0-10 $\mathrm{cm}$ depth layer, there were no significant differences between the native vegetation systems, Cane 8, and Cane 10 systems, in relation to the TOC contents. In Cane 8 system, although the current sugarcane field was oneyear-old, it was cultivated with sugar cane for five years, retaining $100 \%$ of the straw on the soil surface. In Cane 10 system, the current sugarcane field was 5 years old, retaining $20 \%$ of the straw on the soil surface (Figure 1) and, was previously also cultivated with sugar cane, retaining $100 \%$ of the straw on site. It is possible that the long period of maintenance of all the sugarcane straw on the soil surface contributed to the accumulation of carbon on the soil profile.

Table 2

Total organic carbon (TOC), fractionation of soil organic matter in the light fraction, sand fraction, and silt + clay fraction from soil samples collected from different depths of sugarcane systems.

\begin{tabular}{|c|c|c|c|c|c|}
\hline Depth (m) & Cane 6 & Cane 7 & Cane 8 & Cane 10 & Native vegetation \\
\hline & \multicolumn{5}{|c|}{ Total organic carbon $\left(\mathrm{g} \mathrm{kg}^{-1}\right)$} \\
\hline $0,0-0,1$ & $9,1 b A^{*}$ & $8,7 \mathrm{cA}$ & $12,2 \mathrm{abA}$ & $14,5 a b A$ & $14,5 \mathrm{aA}$ \\
\hline $0,1-0,2$ & $8,1 \mathrm{bA}$ & $5,8 \mathrm{cB}$ & $10,7 a A$ & $8,7 a b B$ & $11,2 \mathrm{aB}$ \\
\hline \multirow[t]{2}{*}{$0,2-0,3$} & $6,9 a A$ & $4,7 \mathrm{bB}$ & $9,4 \mathrm{aA}$ & $6,7 \mathrm{abB}$ & $8,7 a B$ \\
\hline & \multicolumn{5}{|c|}{ Light fraction $\left(\mathrm{g} \mathrm{kg}^{-1}\right)$} \\
\hline $0,0-0,1$ & $0,7 a A$ & $2,1 \mathrm{aA}$ & $1,8 \mathrm{aA}$ & $2,4 \mathrm{aA}$ & $1,7 a A$ \\
\hline $0,1-0,2$ & $0,5 a A$ & $0,5 \mathrm{aAB}$ & $0,8 \mathrm{aAB}$ & $0,8 \mathrm{aA}$ & $0,7 a A$ \\
\hline \multirow[t]{2}{*}{$0,2-0,3$} & $0,4 a A$ & $0,1 \mathrm{aB}$ & $0,4 a B$ & $0,4 \mathrm{aA}$ & $0,4 a A$ \\
\hline & \multicolumn{5}{|c|}{ Sand fraction $\left(\mathrm{g} \mathrm{kg}^{-1}\right)$} \\
\hline $0,0-0,1$ & $2,6 \mathrm{bcA}$ & $1,8 \mathrm{cA}$ & $4,6 a A$ & $2,7 a b c A$ & $4,3 a b A$ \\
\hline $0,1-0,2$ & $2,2 \mathrm{aA}$ & $1,4 \mathrm{bA}$ & $2,1 \mathrm{aB}$ & $2,1 \mathrm{aA}$ & $4,5 a A$ \\
\hline \multirow[t]{2}{*}{$0,2-0,3$} & $2,2 a A$ & $1,4 \mathrm{bA}$ & $1,7 \mathrm{aC}$ & $1,6 a A$ & $4,3 a A$ \\
\hline & \multicolumn{5}{|c|}{ Silt+clay fraction $\left(\mathrm{g} \mathrm{kg}^{-1}\right)$} \\
\hline $0,0-0,1$ & $5,9 a b A$ & $4,8 b A$ & $5,7 a b B$ & $9,4 a A$ & $8,5 a A$ \\
\hline $0,1-0,2$ & $5,3 \mathrm{bA}$ & $3,9 \mathrm{cAB}$ & $7,8 \mathrm{aA}$ & $5,9 \mathrm{bAB}$ & $6,0 a b c A B$ \\
\hline $0,2-0,3$ & $4,3 \mathrm{bA}$ & $3,2 \mathrm{bB}$ & $7,3 \mathrm{aAB}$ & $4,7 a b B$ & $4,0 b B$ \\
\hline
\end{tabular}

*Means followed by the same lowercase letter in the row and uppercase in the column do not differ by Student's $t$ test at $5 \%$ probability. 
Our results were similar to those of other studies, which showed that the deposition and maintenance of straw on the soil surface over time increases organic carbon contents, which tend to be equal to or greater than the area of native vegetation used as a reference (Campos, Leite, Maciel, Brasil, \& Iwata, 2013; Signor, Zani, Paladini, Deon, \& Cerri, 2014; Bordonal et al., 2018).

Regarding the sampling depths, the lowest soil carbon contents were observed in the deeper layers of the Cane 7 system (Table 2), possibly due to the growth of beans and soil tillage (plowing and harrowing) for the establishment of the current sugarcane field (Figure 1). Soil tillage, combined with high temperature and humidity (irrigated systems), contributed to the acceleration of organic matter mineralization deposited in the soil surface, decreasing the carbon stocks in the soil (Loss, Pereira, Schultz, Anjos, \& Silva, 2009). This study was carried out in a region that has an annual mean temperature above $20^{\circ} \mathrm{C}$ and the sugarcane fields are irrigated practically throughout the year, which contributes to the fast mineralization of soil organic matter.

The straw accumulation on the soil surface of the sugarcane fields contributes to the increase of soluble organic compounds of low molecular weight and humic substances (fulvic and humic acids) of hydrophobic character, which can move to the deeper layers in the soil (Canellas et al., 2010; Pegoraro,
Moreira, Dias, \& Silveira, 2018). In addition, the roots of sugarcane plants also contribute to the increase in soil organic carbon contents in depth.

Regarding the contribution of different fractions of organic matter to the total soil carbon, in general, the silt + clay fraction $(<53$ $\mathrm{mm}$ ) was the predominant fraction (Table 2). This fraction corresponded to more than $50 \%$ of the fractions of soil organic matter (Figure 2) and is considered the most stable fraction, as it is in a more advanced stage of decomposition and has a longer residence time in the soil (Lisboa, Conant, Haddix, Cerri, \& Cerri, 2009; Signor et al., 2014; Romaniw et al., 2015; Sousa et al., 2018).

The higher proportions of carbon associated with the silt + clay fraction in the sugarcane fields, in relation to the soil with native vegetation (Figure 2), are possibly due to factors that favor the process of mineralization of organic matter, such as the turning of the soil for implementation of the sugarcane fields, irrigation, and correction of soil acidity and fertilization (Rangel \& Silva, 2007; Potes, Dick, Santana, Tomazi, \& Bayer 2012; Rossi, Pereira, Giácomo, Betta, \& Polidoro, 2012). In addition, there was deposition of organic material (straw) in the sugarcane fields, which has recalcitrant compounds, such as lignin, cellulose, and hemicellulose (Alvarenga et al., 2015). 


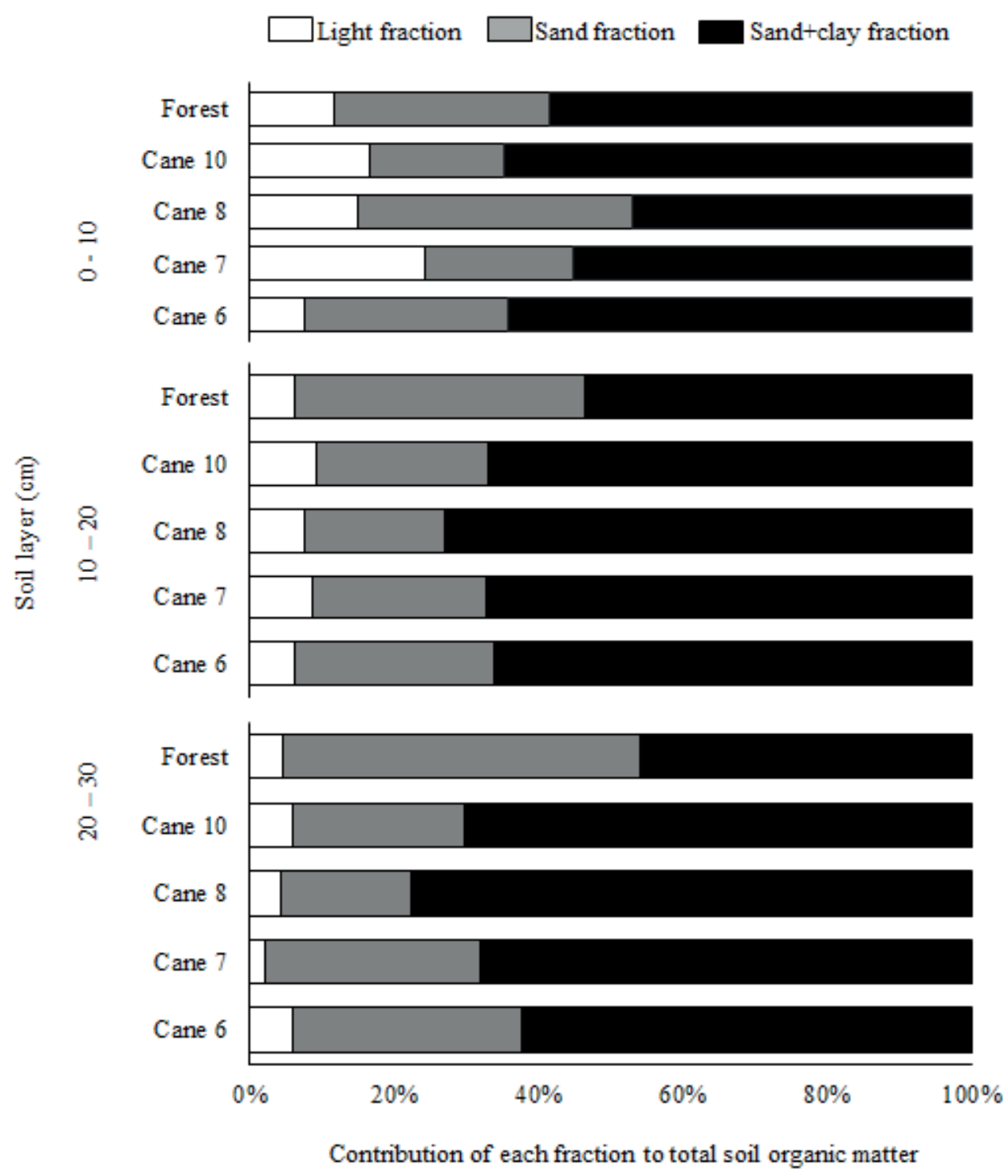

Figure 2. Contribution of fractions of soil organic matter to total organic carbon from soil samples collected from different depths of sugarcane systems.

The Cane 10 system presented the highest values of the silt + clay fraction, which increased with the depth of the soil (Figure 2). This increase is possibly due to the older age of sugarcane field, making the carbon in the current field more stable. Thus, the physical fractions of organic matter are an efficient tool for assessing the effects of the management system on the quality of agricultural soils
(Conceição, Bayerll, Dieckowll, \& Santos, 2014; Romaniw et al., 2015).

For the light fraction, the highest values were observed in the superficial layer (0-10 $\mathrm{cm}$ ) (Figure 2). This fraction is an indicator that can be used to assess the soil physical quality. The light fraction is more sensitive to the land use changes and soil management and corresponds to a small amount of the total 
organic carbon content (Christensen, 1992). In addition to the light fraction, microbial carbon can also be used as an indicator of changes resulting from the land use and soil management (Rangel \& Silva, 2007; Marques et al., 2015). According to the results of the soil organic matter fractionation, a reduction in the light fraction was observed with an increase in the soil sampling depth in all the evaluated systems (Figure 2), proving that this fraction is highly sensitive to the soil management.

The forest system (native vegetation with unmanaged soil) presented the highest values of sand fraction, mainly in the most superficial layer (Figure 2). The sand fraction corresponds to organic matter that was recently deposited in the soil. In this fraction, carbon is in an intermediate stage of decomposition (Christensen, 1992; Signor et al., 2014; Sousa etal., 2018). These results were possibly due to the continuous deposition of leaves and branches by forest species.

In order to group the studied systems according to the physical and chemical attributes of soil, only the $0-10 \mathrm{~cm}$ deep layer was used (Figure 3). This soil layer is the most influenced by sugarcane management practices such as irrigation, mechanization, correction of acidity and fertilization, and deposition of organic residues. According to the dendrogram (Figure 3), there was a significant variation in the values of the Euclidean distance between the systems for the set of variables considered, which made it possible to distinguish three groups: a group formed by the forest (native vegetation), a group formed by Cane 10, and a third group formed by Cane 8, Cane 7, and Cane 6.

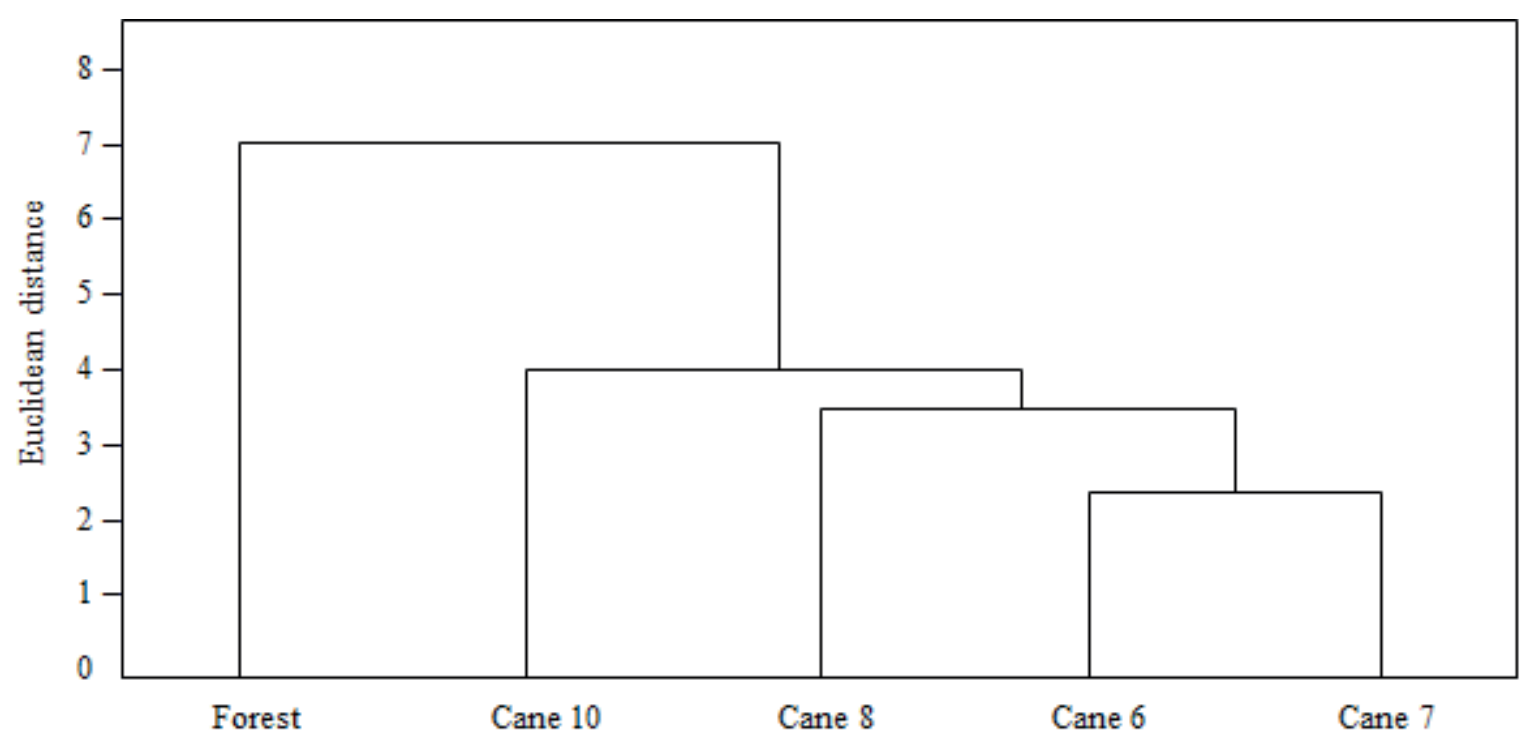

Figure 3. Dendrogram resulting from the hierarchical cluster analysis showing the formation of groups according to physical and chemical attributes (sand and clay contents; soil density and total porosity; available phosphorus, potassium, calcium, magnesium, sulfur, iron contents, manganese, zinc and boron, total organic carbon content; free organic matter fraction, sand fraction, and the fraction associated with silt + clay of organic carbon) from the $0-10 \mathrm{~cm}$ layer depth of the soils of the native vegetation areas, Cane 6, Cane 7, Cane 8, and Cane 10. 
According to the results of the cluster analysis (Figure 3), it was observed that the monoculture of sugarcane without burning (green cane) contributes to the maintenance of soil attributes closer to those of native vegetation (soil under forest) over time (Cane 10). On the other hand, the recent soil tillage for the implementation of a new sugarcane field, contributes to the alterations in the soil attributes, that accumulate over time (Cane 6, Cane 7, and Cane 8). As pointed out by other studies (Pegoraro et al., 2018; Sousa et al., 2018), intensive farming systems provide greater deposition of plant residues in the soil, favoring nutrient cycling and increasing the carbon content in labile fractions over time. However, the excessive usage of machines promotes soil disturbances and, consequently, increases soil density and reduces the capacity to convert organic residues into recalcitrant fractions of soil organic matter in agricultural areas.

\section{Conclusions}

The management of sugarcane field with the maintenance of part of the straw on the soil surface contributes to the preservation of the soil structure and the most stable fractions of organic carbon over time. However, in regions of high annual mean temperature and in irrigated systems, the soil tillage for the renewal of the sugarcane fields significantly decreases the total soil organic carbon.

\section{Acknowledgments}

This research was carried out with support from the Coordenação de
Aperfeiçoamento de Pessoal de Nível Superior (Capes) (Financing Code 88881.068513/20141), the Conselho Nacional de Desenvolvimento Científico e Tecnológico (CNPq) (granting scholarship - process 302997/2020-2), and the Minas Gerais State Foundation for Research Support (FAPEMIG / Brazil). We thank Letícia Silva de Almeida (in memoriam) for her friendship and contributions to this study.

\section{References}

Alvarenga, A. C., Fernandes, L. A., Alonso, J., Santos, L. D. T., Sampaio, R. A., \& Frazão, L. A. (2015). Producción, composición y aporte de nutrientes de hojarasca en sistemas agroforestales. Spanish Journal of Rural Development, 6(4), 85-100. doi: 10.5261/2015.GEN3.09

Alvares, C. A., Stape, J. L., Sentelhas, P. C., Goncalves, J. L. de M., \& Sparovek, G. (2013). Köppen's climate classification map for Brazil. Meteorologische Zeitschrift, 22(6), 711-728. doi: 10.1127/0941-29 $48 / 2013 / 0507$

Bordonal, R. O., Menandro, L. M. S., Barbosa, L. C., Rattan, L., Milori, D. M. B. P., Kolin, O. T.,... Carvalho, J. L. N. (2018). Sugarcane yield and soil carbon response to straw removal in south-central Brazil. Geoderma, 328(1), 79-90. doi: 10.1016/j. geoderma.2018.05.003

Campos, L. P., Leite, L. F. C., Maciel, G. A., Brasil, E. L., \& Iwata, B. F. (2013). Estoques e frações de carbono orgânico em Latossolo Amarelo submetido a diferentes sistemas de manejo. Pesquisa Agropecuária Brasileira, 48(3), 304-312. doi: 10.1590/ S0100-204X2013000300009

Canellas, L. P., Velosso, A. C. X., Marciano, C. R., Ramalho, J. F. G. P., Rumjanek, V. M., 
Rezende, C. E., \& Santos, G. A. (2010). Soil organic matter and nutrient pools under long-term non-burning management of sugar cane. European Journal of Soil Science, 61(1), 375-383. doi: 10.1111/ j.1365-23 89.2010.01229.x

Carvalho, L. M. T., \& Scolforo, J. R. (2008). Inventário florestal de Minas Gerais. Lavras: UFLA.

Christensen, B. T. (1992). Physical fractionation of soil and organic matter in primary particle size and density separates. Advances in Soil Science, 20(1), 1-90. doi: 10.1007/978-1-4612-2930-8_1

Conceição, P. C., Bayerll, C., Dieckowll, J., \& Santos, D. C. dos. (2014). Fracionamento físico da matéria orgânica e índice de manejo de carbono de um Argissolo submetido a sistemas conservacionistas de manejo. Ciência Rural, 44(5), 794800. doi: 10.1590/S0103-84782014005 000004

Instituto Brasileiro de Geografia e Estatística (2017). A geografia da cana-de-açúcar. Rio de Janeiro: IBGE.

Lisboa, C. C., Conant, R. T., Haddix, M. L., Cerri, C. E. P., \& Cerri, C. C. (2009). Soil carbon turnover measurement by physical fractionation at a Forest-to-pasture chronosequence in the Brazilian Amazon. Ecosystems, 12(7), 1212-1221. doi: 10.10 07/s10021-009-9288-7

Loss, A., Pereira, M. G., Schultz, N., Anjos, L. H. C., \& Silva, E. M. R. (2009). Carbono e frações granulométricas da matéria orgânica do solo sob sistemas de produção orgânica. Ciência Rural, 39(4), 1077-1082. doi: 10.1590/S0103-84782009005000036

Luciano, R. V., Albuquerque, J. A., Costa, A., Batistella, B., \& Warmling, M. T. (2012). Atributos físicos relacionados a compactação de solos sob vegetação native em região de altitude no sul do Brasil. Revista Brasileira de Ciência do Solo, 36(6), 1733-1744. doi: 10.1590/ S0100-06832012000600007

Marques, J. D. O., Luizão, F. J., Teixeira, W. G., Sarrazin, M., Ferreira, S. J. F., Beldini, T. P, \& Marques, E. M. A. (2015). Distribution of organic carbon in different soil Fractions in ecosystems of central Amazônia. Revista Brasileira de Ciência do Solo, 39(1), 232-241. doi: 10.1590/01000683rbcs20150142

Pegoraro, R. F., Moreira, C. G., Dias, D. G., \& Silveira, T. C. (2018). Carbon and nitrogen stocks in the soil and humic substances of agricultural crops in the semi-arid region. Revista Ciência Agronômica, 49(4), 574583. doi: 10.5935/1806-6690.20180065

Potes, M. L., Dick, D. P., Santana, G. S., Tomazi, M., \& Bayer, C. (2012). Soil organic matter in fire-affected pastures and in an Araucaria Forest in South-Brasilian Leptosols. Pesquisa Agropecuária Brasileira, 47(5), 707-715. doi: 10.1590/S0100-204X201 2000500011

Rangel, O. J. P., \& Silva, C. A. (2007). Estoques de carbono e nitrogênio e frações orgânicas de Latossolo submetido a diferentes sistemas de uso e manejo. Revista Brasileira de Ciência do Solo, 31(6), 1609-1623. doi: 10.1590/S010006832007000600037

Romaniw, J., Sá, J. C. M., Padilha, A. A., Ramos, F. S., Eurich, G., \& Bressan, P. T. (2015). Carbon dynamics in no-till soil due to the use of industrial organic waste and mineral fertilizer. Revista Ciência Agronômica, 46(3), 477-487. doi: 10.5935/1806-66 90.20150029

Rossi, C. Q., Pereira, M. G., Giácomo, S. G., Betta, M., \& Polidoro, J. C. (2012). Frações lábeis da matéria orgânica em sistema de cultivo 
com palha de braquiária e sorgo. Revista Ciência Agronômica, 43(1), 38-46. doi: 10.1590/S1806-66902012000100005

Signor, D., Zani, C. F., Paladini, A. A., Deon, M. D., \& Cerri, C. E. P. (2014). Estoques de carbono e qualidade da matéria orgânica do solo em áreas cultivadas com canade-açúcar. Revista Brasileira de Ciência do Solo, 38(5), 1402-1410. doi: 10.1590/ S0100-06832014000500005

Silva, A. S., Silva, I. F., Ferreira, L. E., Borchartt, L., Souza, M. A., \& Pereira, W. E. (2013). Propriedades físicas e químicas em diferentes usos do solo no Brejo Paraibano. Revista Brasileira de Ciência do Solo, 37(4), 1064-1072. doi: 10.1590/ S0100-06832013000400023

Simões, W. L., Calgaro, M., Coelho, D. S., Souza, M. A. de, \& Lima, J. A. (2015). Respostas de variáveis fisiológicas e tecnológicas da cana-de-açúcar a diferentes sistemas de irrigação. Revista Ciência Agronômica, 46(1), 11-20. doi: 10.1590/S1806-6690 2015000100002
Sousa, J. G. D. A., Jr., Cherubin, M. R., Oliveira, B. G., Cerri, C. E. P., Cerri, C. C., \& Feigl, B. J. (2018). Three-year soil carbon and nitrogen responses to sugarcane straw management. BioEnergy Research, 11(2), 249-261. doi: 10.1007/s12155-017-989 $2-x$

Spera, S. T., Santos, H. P., Fontaneli, R. S., \& Tomm, G. O. (2008). Dispersão de argila em microagregados de solo incubado com calcário. Revista Brasileira de Ciência do Solo, 32(1), 2613-2620. doi 10.1590/S 0100-06832008000700002

Teixeira, P. C., Donagemma, G. K., Fontana, A., \& Teixeira, W. G. (2017). Manual de métodos de análise de solo. Rio de Janeiro: EMBRAPA Solos. 
